\title{
Phenotypic plasticity in larval development and size at metamorphosis in Rhinella spinulosa (Anura: Bufonidae) from Salta, Argentina
}

\author{
Emma Anhyela Guantay, Norma Rebeca Acosta, and Héctor Alejandro Núñez \\ Escuela de Biología de la Facultad de Ciencias Naturales and Consejo de Investigación de la Universidad Nacional de Salta. \\ Av. Bolivia 5150, Salta, Argentina. E-mails: emmaguantay@unsa.edu.ar, racosta@unsa.edu.ar, alenunez.1964@gmail.com.
}

\begin{abstract}
Phenotypic plasticity in larval development and size at metamorphosis in Rhinella spinulosa (Anura: Bufonidae) from Salta, Argentina. Phenotypic plasticity typically is induced by environmental heterogeneity or stress, and is manifest by changes in behavior, morphology, or physiology. In amphibians, phenotypic variation is strongly influenced by the quality of the aquatic environment in which larvae develop. The stability of the aquatic environment and conspecific density are two important environmental stressors. We investigated whether larval populations of Rhinella spinulosa subject to varying levels of hydroperiod and intraspecific competition exhibit phenotypic plasticity in their life-history characteristics. Egg clutches were collected from an arid region, within Parque Nacional Los Cardones. Larvae were exposed to different levels of hydroperiod and conspecific density in the laboratory. Development time and size at metamorphosis were recorded. Our results show that larvae from different clutches respond plastically in their life- history traits. Conspecific density was the most influential variable.
\end{abstract}

Keywords: body size, development time, metamorphosis, Parque Nacional Los Cardones.

\footnotetext{
Resumen

Plasticidad fenotípica en el desarrollo larval y el tamaño en la metamorfosis en Rhinella spinulosa (Anura: Bufonidae) en Salta, Argentina. La plasticidad fenotípica es normalmente inducida por la heterogeneidad o el estrés ambiental, causando cambios en el comportamiento, la morfología o la fisiología. En los anfibios, una de las principales causas de variación está relacionada con la calidad del ambiente acuático en el que se desarrollan las larvas. La inestabilidad del medio acuático y la densidad de conspecíficos son importantes factores de estrés ambiental. Nuestro estudio tuvo como objetivo analizar comparativamente la existencia de respuestas plásticas en características de historia de vida de poblaciones larvales de Rhinella spinulosa, frente a presiones ambientales de
}

Received 24 May 2013.

Accepted 13 November 2013.

Distributed December 2013. 
hidroperiodo y competencia intraespecifica. Para ello trabajamos con puestas provenientes de ambientes protegidos del Parque Nacional Los Cardones, de regiones áridas. En laboratorio las larvas fueron expuestas a diferentes hidroperiodos y densidades de coespecificos, registrándose el tiempo y tamaño en la metamorfosis. Nuestros resultados evidencian que larvas provenientes de diferentes nidos pueden responder plásticamente en sus rasgos de historia de vida. La variable de mayor influencia fue la densidad de coespecíficos.

Palabras clave: metamorfosis, Parque Nacional Los Cardones, tamaño del cuerpo, tiempo de desarrollo.

\begin{abstract}
Resumo
Plasticidade fenotípica no desenvolvimento larval e no tamanho à metamorfose em Rhinella spinulosa (Anura: Bufonidae) de Salta, Argentina. A plasticidade fenotípica é tipicamente induzida por heterogeneidade ou estresse ambiental e se manifesta na forma de mudanças de comportamento, morfologia ou fisiologia. Nos anfíbios, a variação fenotípica é fortemente influenciada pela qualidade do ambiente aquático em que as larvas se desenvolvem. A estabilidade do ambiente aquático e a densidade de coespecíficos são dois importantes fatores de estresse. Investigamos se populações larvárias de Rhinella spinulosa sujeitas a níveis variáveis de hidroperíodo e de competição intraespecífica exibem plasticidade fenotípica em características da história de vida. Desovas foram coletadas em uma região árida do Parque Nacional Los Cardones. As larvas foram expostas a diferentes níveis de hidroperíodo e de densidade coespecífica no laboratório. Foram registrados o tempo de desenvolvimento e o tamanho à metamorfose. Nossos resultados mostram que larvas de diferentes desovas respondem plasticamente em suas características de história de vida. A densidade coespecífica foi a variável mais influente.
\end{abstract}

Palavras-chave: metamorfose, Parque Nacional Los Cardones, tamanho do corpo, tempo de desenvolvimento.

\section{Introduction}

The adaptive variation in a phenotypic trait in response to the environment is known as adaptive phenotypic plasticity (Sultan 2004, Pigliucci 2005). Phenotypic plasticity is typically induced by environmental heterogeneity or stress, and is manifest by changes in behavior, morphology, or physiology (Garland and Kelly 2006). The quality of the aquatic environment has a primary influence on phenotypic plasticity in amphibians. For example, if ponds are ephemeral, larvae must reach metamorphosis quickly before the pond dries to survive (Loman 2003, Johansson et al. 2010). Studies in which pond desiccation and depth have been manipulated have revealed that larvae in shortduration ponds development more rapidly than those in long-duration ponds. Studies also demonstrate a positive correlation between size at metamorphosis and the length of the larval period (Denver et al. 1998, Newman 1988a, Boorse and Denver 2004).

As water is reduced in short-duration ponds, larval density increases, along with competition for resources among conspecifics; this accelerates the onset of metamorphosis (Merilä et al. 2000b). Morey and Reznick (2001) evaluated the effects of larval density and metamorphic body size on survival in Spea hammondii and found that smaller metamorphs had higher mortality rates than larger ones, indicating an advantage of large size at metamorphosis. These and other studies indicate that variation in hydroperiod and intraspecific competition exert different selection pressures on life-history traits, such as the 
duration of the larval period and size at metamorphosis (Loman 2002, Richter Boix et al. 2006, Acosta and Kehr 2010). In anurans that oviposit in water bodies with variable drying rates, such as Rhinella spinulosa (Wiegmann, 1834), the primary threat to larval survival is the disappearance of water before metamorphosis (Wells 2007). In unpredictable environments, selection may favor the development of plastic responses that facilitate escape from a drying environment (Richter Boix et al. 2011). Although a long development time and a large size at metamorphosis may increase fitness at adulthood (Morey and Reznick 2001), a short development time may enhance larval fitness under the threat of desiccation (Newman 1988a, 1992).

Phenotypic plasticity tends to evolve in a population when the fitness of individuals with plastic responses exceeds that of individuals with fixed responses (Garland and Kelly 2006). Depending on the degree of isolation, the extent of plasticity may vary among populations (Lind and Johansson 2009). An experimental system of temporary and permanent ponds with different selection pressures can be used to study phenotypic plasticity and variation among populations (Newman 1992, Lind et al. 2011). The western, high-altitude region of Salta Province, Argentina, is a stressful environment for populations of Rhinella spinulosa and well suited for the study of phenotypic plasticity. Populations of these toads are geographically isolated from one another in this region, with ponds distributed as patches in an arid matrix. Our study aimed to investigate phenotypic plasticity in the life-history characteristics of larval populations of $R$. spinulosa from Salta Province in response to variation in hydroperiod and intraspecific competition.

\section{Materials and Methods}

Rhinella spinulosa is broadly distributed thoughout the Andes from southern Ecuador, through the intermontane valleys of Peru and Chile, and into southern Argentina (Cei 1980). It is considered a focal species in the study area because of its persistence and abundance in ponds, and its habit of reproducing in both temporary and permanent water bodies (Acosta and de Viana 1998).

Egg clutches were collected from two study sites: Río Tin-Tin, characterized by a broad and irregular riverbed and a temporary watercourse $\left(25^{\circ} 11^{\prime} \mathrm{S}, 66^{\circ} 0^{\prime} \mathrm{W}\right)$, and Río Calchaquí, with a permanent watercourse $\left(25^{\circ} 03^{\prime} \mathrm{S}, 66^{\circ} 06^{\prime} \mathrm{W}\right)$. In both study sites was collected one egg clutches.

Aquatic environments at each site were visited during the breeding season (OctoberDecember 2011) to identify reproductive adults and collect egg samples from spawn. Egg samples were collected on 05 (Río Tin-Tin) and 14 November (Río Calchaquí) and transported to the laboratory, where they were maintained in aquaria until hatching. The newly hatched larvae then were transported to aquaria with dechlorinated water. Water changes occurred every seven days. Water temperature $\left(25 \pm 2^{\circ} \mathrm{C}\right)$ and photoperiod (16:8 hours) were maintained at levels corresponding to the native environments.

Experiments began at larval Stage 26 (Gosner 1960), with one population per experiment. Larvae from each nest were assigned at random to the experimental treatments. Assays were performed in plastic $4000-\mathrm{ml}$ containers $(22 \mathrm{~cm}$ diameter $\times 14 \mathrm{~cm}$ height). Larvae from each nest received two treatments-one involving larval density and another water volume. In the highdensity treatment, there were 30 larvae, whereas in the low density treatment, there were 10 larvae. Three variations in water volume were tested: (1) high constant volume (3000 ml); (2) low constant volume (1000 ml); and (3) decreasing volume (from 3000-1000 ml, decreased by $500 \mathrm{ml}$ every 7 days). Treatments 1 and 2 simulated permanent environments, whereas Treatment 3 simulated a desiccating body of water. Each experiment consisted of six treatments with four replicates, resulting in a total of 24 trials for each population and 480 larvae in each experiment. Larvae were fed $a d$ libitum with Tetra ${ }^{\circledR}$ fish food pellets. 


\section{Measurements}

Body length (snout-vent), weight (wet weight), and development time were recorded for each individual at metamorphosis. Individuals with a tail length less than $30 \%$ of their body length were considered metamorphic (Loman 2003). Length was recorded with digital calipers $\left(0 / 100^{\circ}, 0.01\right.$ $\mathrm{mm}$ resolution), and weight was measured with an analytical balance (Mettler Toledo AB 204). Development time was measured as the number of days elapsed between the start of the experiment (Gosner Stage 26) and metamorphosis. The experiment ended on the 35th day (Acosta 2010).

\section{Statistical Analysis}

The data were LN-transformed to meet normality assumptions. The growth rate was calculated by dividing the natural logarithm of weight by the natural logarithm of development time (Kehr 1991), with development time defined as the number of days elapsed between the start of the experiment and metamorphosis.

These data were used to test the effects of hydroperiod and density on the growth and morphology of metamorphic individuals in each environment. Tests were performed using analyses of variance (ANOVA). For the test of survival (the number of individuals reaching metamorphosis), a $\chi^{2}$ with Yates correction for continuity was used to verify any differences between treatments in the number of metamorphs. Statistical tests were performed using the software Infostat version 2011 (Di Rienzo et al. 2011).

\section{Results}

\section{Survival}

Survival was higher in the high-density treatment in both clutches $\left(\chi^{2}=32.81, \mathrm{df}=1, p\right.$ $<0.0001 ; \chi^{2}=17.44$, df $\left.=1, p<0.0001\right)$.

A significant effect of water volume on survival was observed only in the Río Tin-Tin clutch (Río Tin-Tin: $\chi^{2}=6.92$, df $=2, p=$
0.0314; Río Calchaqui: $\chi^{2}=4.78$, df $=2, p=$ 0.0915), with greater survival in the low (Treatment 2, $\mathrm{N}=148$ ) and decreasing volume (Treatment 3,N=155) treatments than in the high-volume treatment (Treatment $1, N=114$ ).

\section{Development Time}

Development time differed significantly between density treatments (Table 1, Figure 1A). Individuals from the high-density treatment developed more slowly than those from the lowdensity treatment. There was no observed effect of hydroperiod on development time (Table 1, Figure 1A and D).

\section{Body Length at Metamorphosis}

There were significant effects of density treatment and water-volume treatment on body length at metamorphosis (Table 1). Body length was greater in the low-density treatment than in the high-density treatment (Figure 1B). At low density, metamorphs of one clutch were smaller than those of the Río Tin-Tin; however, the opposite pattern was observed at high density. A significant effect of water volume on body length was observed only in the Río Calchaqui clutch (ANOVA $\mathrm{F}=17.00, p<0.0001, \mathrm{df}=2$, Figure $1 \mathrm{~B}$ ), with significantly greater lengths (Tukey, $p$ $<0.05)$ in the high volume treatment $(2.42 \pm$ $0.01)$ than in the decreasing- $(2.39 \pm 0.01)$ and low-volume $(2.37 \pm 0.01)$ treatments.

\section{Weight at Metamorphosis and Growth Rate}

Both weight at metamorphosis and growth rate were significantly greater at low density (weight: $5.25 \pm 0.02$; growth rate: $1.56 \pm 0.01$ ) than at high density (weight: $5.04 \pm 0.01$; growth rate: $1.46 \pm 0.01$ ) (Table 1, Figure 1C).

\section{Discussion}

Larvae of Rhinella spinulosa from different clutches exhibit phenotypic plasticity in several 

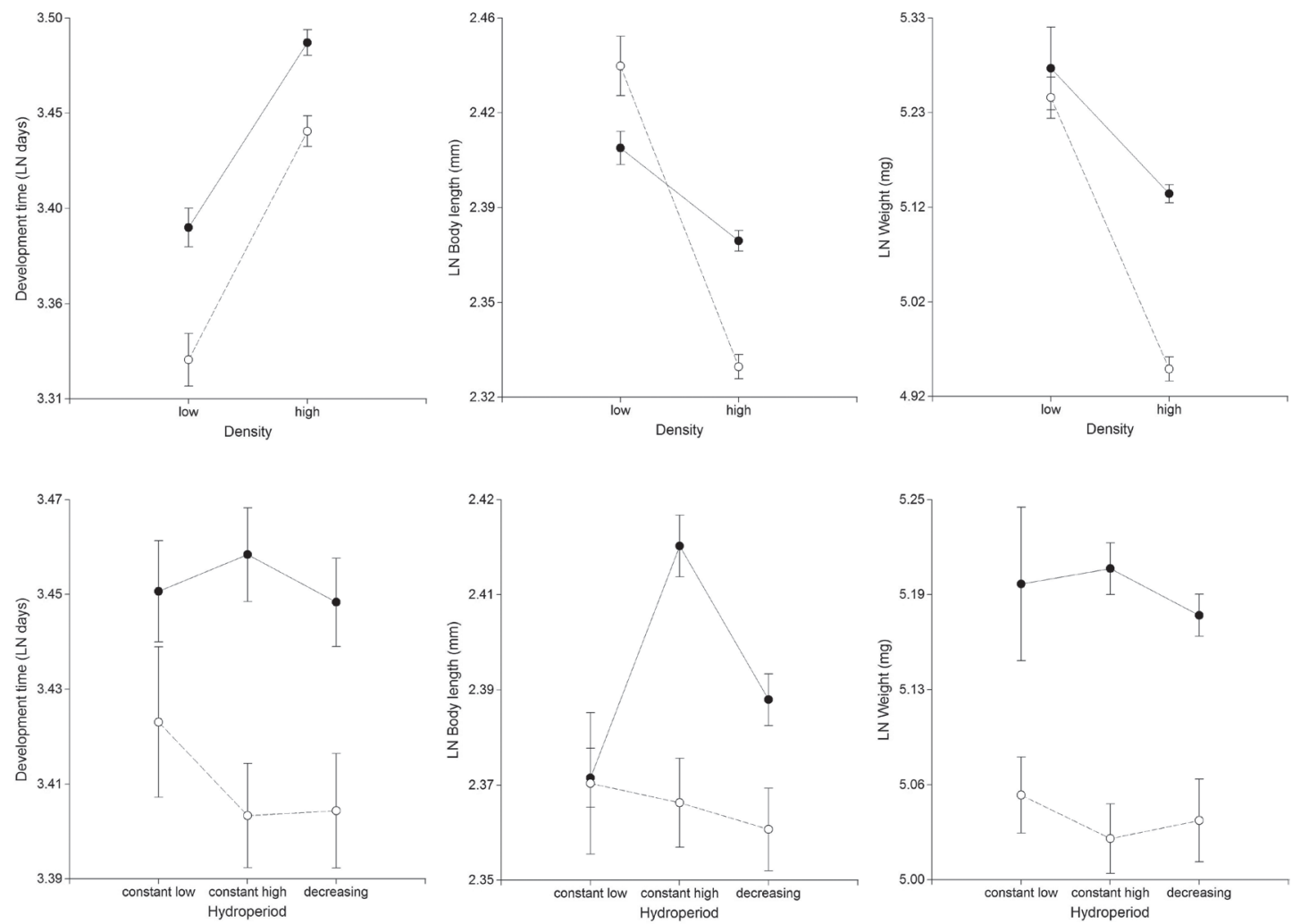

Figure 1. Development time, body length and weight at metamorphosis for each treatment (density, water volume). Open symbols and dashed lines represent clutch from Río Tin-Tin; filled symbols and solid lines correspond that from Río Calchaqui. Dots represent means; bars represent standard deviations.

Table 1. Results of ANOVA of the effects of density and hydroperiod on the development time, body length, weight, and growth rate of larvae at metamorphosis.

\begin{tabular}{|c|c|c|c|c|c|c|c|c|c|c|c|c|}
\hline & \multicolumn{3}{|c|}{ Development time } & \multicolumn{3}{|c|}{ Body length } & \multicolumn{3}{|c|}{ Weight } & \multicolumn{3}{|c|}{ Growth Rate } \\
\hline & $d f$ & $\mathrm{~F}$ & $p$ & df & $\mathrm{F}$ & $p$ & $\mathrm{df}$ & $\mathrm{F}$ & $p$ & df & $\mathrm{F}$ & $p$ \\
\hline Density & 1 & 132.13 & $<0.0001$ & 1 & 122.88 & $<0.0001$ & 1 & 72.09 & $<0.0001$ & 1 & 208.16 & $<0.0001$ \\
\hline Hydroperiod & 2 & 0.14 & 0.8673 & 2 & 8.16 & 0.0003 & 2 & 0.04 & 0.9613 & 2 & 0.01 & 0.9983 \\
\hline $\begin{array}{l}\text { Density* } \\
\text { Hydroperiod }\end{array}$ & 2 & 0.57 & 0.5659 & 2 & 4.04 & 0.0181 & 2 & 0.60 & 0.5503 & 2 & 0.21 & 0.8145 \\
\hline
\end{tabular}


life history traits in response to varying environmental conditions. The most influential variable in our study was the density of conspecifics. Larvae were heavier at low density, potentially reflecting reduced intraspecific competition. Our results are consistent with previous studies demonstrating that biological factors such as intra- and interspecific competition, community composition and predation influence the survival, size at metamorphosis, and time of metamorphosis of anurans (Lardner 2000, Morey and Reznick 2001, Loman 2002, Gómez and Kehr 2011).

Our findings suggest that larvae can accelerate metamorphosis in response to high levels of competition at the cost of reduced body size. Other studies have also found that high densities and low levels of food result in a smaller size at metamorphosis (Morey and Reznick 2001, Rudolf and Rödel 2007). Size at metamorphosis is an important determinant of amphibian fitness because it is positively correlated with juvenile survival and reproductive success (Loman 2001). The observed decrease in body size at high density is consistent with previous work; however, the corresponding increase in development time is not. This latter finding may be due to increased competition, primarily in foraging activity, at high densities. Although individuals responded plastically to the pressures of competition, this response cannot be considered adaptive (Pigliucci et al. 2006) because metamorphosis is delayed at high densities.

In the present study, survival was consistently higher in the high-density treatment. This result may reflect benefits arising through the communal search of food and/or physiological responses that involve temperature regulation (Acosta 2010). However, body size at metamorphosis was greater at low density. This result suggests that, at high density, there is a trade-off between the advantages of denser aggregations, as evidenced by increased survival, and the disadvantages of intraspecific competition (either via interference or exploitation), as evidenced by a smaller size at metamorphosis (Acosta 2010).

There was a significant effect of hydroperiod on the survival of larvae from one clutch, with greater survival in the low-volume and decreasing-volume treatments than in the highvolume treatment. These results indicate plasticity in response to varying stability of the water body. Although there were no apparent effects of hydroperiod on plasticity within each clutch, the differences observed between egg clutches suggest potentially adaptive responses at the population level. This is consistent with other studies that suggest that, in species occupying unpredictable aquatic environments, selection may favor plastic responses during development specifically, an increase in developmental rate and a corresponding decrease in larval period duration to escape a drying environment (Newman 1988a, b, 1992). This response is also consistent with theoretical models suggesting that species occupying stressful environments have evolved toward a smaller size to reduce development time (Day and Rowe 2002).

Larvae of Rhinella spinulosa reach metamorphosis at smaller body sizes in temporary water bodies than in permanent water bodies (Morey and Reznick 2004, Richter-Boix et al. 2011), potentially explaining the difference in development time observed between the two clutches in the present study.

However, we observed no effect of watervolume treatment on development time. This result may reflect strong selection for rapid development or an inability to accelerate development further (Laurila et al. 2002, Merilä et al. 2004, Lind et al. 2008). We also observed that development time was clutch related and that metamorphosis occurred at a smaller size. These results may reflect local adaptation in life history traits in response to different environmental conditions; larvae from temporary water bodies are exposed to increased water stress, whereas those from permanent water bodies experience more stable environments 
(Merilä et al. 2000a, Morey and Reznick 2004, Lind et al. 2008). However, we consider a more integrated explanation of these observations must involve more populations, to understand the relationships among variation in life history traits and local adaptation.

In conclusion, we show that larvae from different clutches are phenotypically plastic in their life history traits. Anurans in stressful or ephemeral aquatic environments respond by changing their development (Wells 2007). Species that occupy both stable and unstable environments may show differential responses depending on those factors most important to fitness. These results are a starting point for future research on the origin of variation in phenotypic plasticity among populations (Lind and Johansson 2007) and the processes leading to local adaptation (Lardner 2000), and probed that $R$. spinulosa is a good model to study plasticity.

\section{Acknowledgments}

This research was partially supported by the Consejo de Investigación de la Universidad Nacional de Salta (CIUNSa) and Consejo Interuniversitario Nacional (CIN) from Argentina through a grade fellowship to E. A. Guantay.

\section{References}

Acosta, R. and M. de Viana. 1998. Ciclo reproductivo de Bufo spinulosus (Anura, Bufonidae), en el Valle de Tin Tin, Argentina. Boletín de la Sociedad de Biología de Concepción 69: 17-20.

Acosta, R. 2010. Plasticidad fenotípica en la metamorfosis de larvas de Rhinella arenarum del Valle de Lerma, Salta. Unpublished Doctoral Thesis. Universidad Nacional de La Plata. Argentina.

Acosta, R. and A. Kehr. 2010. Analysis of the variations, at an intermediate regional scale, of life history traits of Rhinella arenarum using reciprocal transplant experiments. Métodos en Ecología \& Sistemática 5: 16-29.

Boorse, G. and R. Denver. 2004. Endocrine mechanisms underlying plasticity in metamorphic timing in spadefoot toads. Integrative and Comparative Biology 43: 646657.
Cei, J. M. 1980. Amphibians of Argentina. Monitore Zoologico Italiano. N.S. Monografía 2.

Day, T. and L. Rowe. 2002. Developmental thresholds and the evolution of reaction norms for age and size at lifehistory transitions. American Naturalist 159: 338-350.

Denver, R., N. Mirhadi, and M. Phillips. 1998. Adaptive plasticity in amphibian metamorphosis: response of Scaphiopus hammondii tadpoles to habitat dessication. Ecology 79: 1859-1872.

Di Rienzo J. A., F. Casanoves, M. G. Balzarini, L. Gonzalez, M. Tablada, and C. W. Robledo. 2011. Grupo InfoStat, FCA, Universidad Nacional de Córdoba, Argentina. InfoStat versión 2011. URL http://www.infostat.com.ar.

Garland, T. and S. A. Kelly. 2006. Phenotypic plasticity and experimental evolution. The Journal of Experimental Biology 209: 2344-2361.

Gómez V. and A. I. Kehr. 2011. Morphological and developmental plasticity in larvae of Physalaemus santafecinus (Anura: Leiuperidae) in response to chemical cues of different predators. Phyllomedusa 10: 143-151.

Gosner, K. 1960. A simplified table for staging anuran embryos and larvae with notes on identification. Herpetologica 16: 183-190.

Johansson F., B. Lederer, and M. I. Lind. 2010. Trait performance correlations across life stages under environmental stress conditions in the Common Frog, Rana temporaria. Plos One 5: e11680.

Kehr, A. I. 1991. Density-dependent responses in tadpoles of Bufo arenarum (Anura, Bufonidae). Physis 49: 31-36.

Lardner, B. 2000. Phenotypic plasticity and local adaptation in tadpoles. Unpublished Doctoral Thesis. Lund University. Sweden.

Laurila, A., S. Karttunen, and J. Merilä. 2002. Adaptive phenotypic plasticity and genetics of larval life histories in two Rana temporaria populations. Evolution 56: 617627.

Lind, M. I. and F. Johansson. 2007. The degree of phenotypic plasticity is correlated with the spatial environmental heterogeneity experienced by island populations of Rana temporaria. Journal of Evolutionary Biology 20: 12881297.

Lind, M. I. and F. Johansson. 2009. Costs and limits of phenotypic plasticity in island populations of the common frog Rana temporaria under divergent selection pressures. Evolution 63: 1508-1518.

Lind, M. I., P. K. Ingvarsson, H. Johansson, D. Hall, and F. Johansson. 2011. Gene flow and selection on phenotypic plasticity in an island system of Rana temporaria. Evolution 65: 684-697. 
Lind, M. I., F. Persbo, and F. Johansson. 2008. Pool desiccation and developmental thresholds in the common frog, Rana temporaria. Proceedings of the Royal Society B 275: 1073-1080.

Loman, J. 2001. Intraspecific competition in tadpoles, does it matter in nature? A field experiment. Population Ecology 43: 253-263.

Loman, J. 2002. Rana temporaria metamorph production and population dynamics in the field. Effects of tadpole density, predation and pond drying. Journal for Nature Conservation 10: 95-107.

Loman, J. 2003. Growth and development of larval Rana temporaria: local variation and countergradient selection. Journal of Herpetology 37: 595-602.

Merilä, J., A. Laurila, and B. Lindgren. 2004. Variation in the degree and costs of adaptive phenotypic plasticity among Rana temporaria populations. Journal of Evolutionary Biology 17:1132-40.

Merilä, J., A. Laurila, A. T. Laugen, K. Räsänen, and M. Pahkala. 2000a. Plasticity in age and size at metamorphosis in Rana temporaria-comparison of high and low latitude populations. Ecography 23:457465.

Merilä, J., A. Laurila, M. Pahkala, K. Räsänen, and A. T. Laugen. 2000b. Adaptive phenotypic plasticity in timing of metamorphosis in the Common Frog Rana temporaria. Ecoscience 7:18-24.

Morey, S. and D. Reznick. 2001. Effects of larval density on postmetamorphic spadefoot toads (Spea hammondii). Ecology 82: 510-522.

Morey, S. and D. Reznick. 2004. The relationship between habitat permanence and larval development in California spadefoot toads: field and laboratory comparisons of developmental plasticity. Oikos 104: 172-190.
Newman, R. 1988a. Adaptative plasticity in development of Scaphiopus couchii tadpoles in desert ponds. Evolution 42: 774-783.

Newman, R. 1988b. Genetic variation for larval anuran (Scaphiopus couchii) development timen and uncertain environment. Evolution 42: 763-773.

Newman, R. 1992. Adaptative plasticity in amphibians metamorphosis. BioScience 42: 671-678.

Pigliucci, M. 2005. Evolution of phenotypic plasticity: where are we going now? Trends Ecology and Evolution 20: 481-486.

Pigliucci, M., C. J. Murren, and C. D. Schlichting. 2006. Phenotypic plasticity and evolution by genetic assimilation. The Journal of Experimental Biology 209: 2362-2367.

Richter-Boix, A., G. A. Llorente, and A. Montori. 2006. Effects of phenotypic plasticity on post-metamorphic traits during pre-metamorphic stages in the anuran Pelodytes punctatus. Evolutionary Ecology Research 8: 309-320.

Richter-Boix, A., M. Tejedo, and E. L. Rezende. 2011. Evolution and plasticity of anuran larval development in response to desiccation. A comparative analysis. Ecology and Evolution 1: 15-25.

Rudolf, V. H. W. and M. O. Rödel. 2007. Phenotypic plasticity and optimal timing of metamorphosis under certain time constraints. Evolutionary Ecology 21: 121-142.

Sultan, S. E. 2004. Promising directions in plant phenotypic plasticity. Perspectives in Plant Ecology, Evolution and Systematics 6: 227-233.

Wells, K. D. 2007. The Ecology and Behavior of Amphibians. Chicago and London. The University of Chicago Press. $1148 \mathrm{pp}$. 